\title{
SUBCONTRATAÇÃO E CESSÃO DE CONTRATO ADMINISTRATIVO
}

\author{
LEON FREJDA SZKLAROWSKY
}

1. Doutrina. 2. Subcontratação. 3. Cessão do contrato. 4. Direito comparado. 5. Jurisprudência. 6. Conclusão. 7. Concluindo.

A Lei de Licitaçōes e Contratos - Lei 8.666, de 21 de junho de 1993, e suas alterações posteriores, regula a matéria, objeto do questionamento, nos artigos $72 \mathrm{e}$ 78 , inciso VI.

$O$ artigo 72 dispõe que:

“O contratado, na execução do contrato, sem prejuízo das responsabilidades contratuais e legais, poderá subcontratar partes de obra, serviço ou fornecimento, até o limite admitido, em cada caso, pela Administração.

$O$ artigo 78 comanda:

"Constituem motivo para rescisão do contrato:

VI - a subcontratação total ou parcial do seu objeto, a associação do contratado com outrem, a cessão ou transferência, total ou parcial, bem como a fusão, cisão ou incorporação, não admitidas no edital e no contrato;..."

\section{Doutrina}

O contrato é o assentimento de duas ou mais pessoas sobre o mesmo objeto, na expressão genial de ULPIANO, e tanto ARISTÓTELES, quanto KANT e, modernamente, a escola de KELSEN, consideram o contrato uma norma criada por particulares, mas, na precisa conceituação de CLOVIS BEVILAQUA, é o acordo de vontades para o fim de adquirir, resguardar, modificar ou extinguir direitos.

É a associação de duas ou mais vontades, o acordo de duas ou mais pessoas, tendo em vista determinado objeto, e sua validade pressupõe necessariamente a pessoa capaz, objeto lícito e forma prescrita e não proibida por lei. Neste sentido, WASHINGTON DE BARROS MONTEIRO.

No direito contratual público, o conceito de contrato não difere substancialmente, a não ser pela só presença da Administração Pública, que derroga normas de 
direito privado, conforme as lições de HELY LOPES MEIRELLES e da doutrina proeminente. A formalidade, contudo, é essencial e não pode ser negligenciada. Dada a supremacia de poder. a contratante adquire certas prerrogativas, em vista do interesse público, respeitados os direitos da contratada. que pode ser a pessoa física ou jurídica signatária de contrato com a Administração Pública, abrangendo esta a administração direta e a indireta, da União, dos Estados, do Distrito Federal e dos Municípios, incluindo todas as entidades com personalidade jurídica de direito privado. sob controle do poder público e das fundações por ele instituídas ou mantidas (artigo 6뭉 incisos XIV e XV, da Lei 8.666/93).

O contrato administrativo é, em regra, por sua natureza, pessoal, daí por que. cumprindo preceito constitucional, através da licitação, a Administração Pública examina a capacidade e a idoneidade da contratada, cabendo-lhe executar pessoalmente o objeto do contrato, sem transferir as responsabilidades ou subcontratar, a não ser que haja autorização da contratante. Suas cláusulas e as normas de direito público regem-no diretamente, aplicando-se-lhe, supletivamente, os princípios da teoria geral dos contratos e as disposições de direito privado, numa perfeita miscigenação e sincronia.

Contrato pessoal, contudo, não significa necessariamente personalíssimo. A instabilidade, na execução do contrato, advém do interesse público, daí por que, no discurso do Ministro JOSÉ AUGUSTO DELGADO,

"não se pode conceber contrato administrativo sem ser condicionado ao interesse público, Este não se apresenta imutável" (cf. Revista de Direito Público 62/123 e segs.).

Observa ainda o autor que, na execução do contrato administrativo, a responsabilidade é da própria pessoa com quem se contratou, todavia essa regra admite exceções e, fundado, no magistério de MARCELO CAETANO, indica, com tranquiilidade, que:

"a execução do contrato pode prosseguir por pessoa diferente daquela com quem inicialmente foi estipulado quando as prestações não tiverem por objeto serviços de caráter pessoal e a Administração consinta na substituição, tendo em conta as exigências legais relacionadas com a capacidade e a idoneidade do concessionário ou do sucessor" (cf. op. e p. cits.).

Também CARLOS ROBERTO PELLEGRINO, escudado na melhor doutrina, inclina-se por esse entendimento (cf. Revista de Direito Público, 92/139).

Eis aqui nascendo a verdadeira simbiose entre o direito público e privado, que GUILLERMO ANDRÉS MUÑOZ descreve, com muita sensibilidade, e rechaça a divisão esotérica entre o direito público e privado. porque tais dogmas sofrem, na atualidade, violenta crise e conclui que é muito difícil sustentar a romana contraposição entre o direito público e privado, calcada na idéia de um Estado regulado por princípios especiais e opostos aos do direito privado (cf. Revista de Direito Público, 91/19-27).

Deste pensar é também o procurador e escritor MARCOS JURUENA VILLELA SOUTO. quando escreve que o contrato administrativo vai abeberar-se na fonte do direito privado, mais precisamente na teoria geral dos contratos, para captar seus 
elementos essenciais aos quais vais justapor suas prerrogativas que lhe marcam as características (cf. Licitações \& Contratos Administrativos, ADCOAS. Esplanada, $2^{\mathrm{a}}$ edição, I/170).

HELY LOPES MEIRELLES confirma que o contrato administrativo é realizado intuitu personae, porquanto visa sempre a pessoa jurídica ou física do contratado, mas nada impede que o contratado confira partes da obra e certos serviços técnicos a artífices ou a empresas especializadas, porque, aduz, se o contrato é pessoal, nem sempre é personalíssimo, visto que:

"Modernamente, a complexidade das grandes obras e a diversificação de instalações e equipamentos dos serviços públicos exigem a participação de diferentes técnicos e especialistas, o que fica subentendido nos contratos desse tipo" (cf. Licitação e Contrato, $11^{\underline{a}}$ edição atualizada por EURICO ANDRADE AZEVEDO e CÉLIA MARISA PRENDES, Malheiros, 1996, p. 189).

O direito brasileiro é bastante incisivo, permitindo o artigo 72 do diploma legal, sob comento, a subcontratação de partes da obra, serviço e fornecimento, até o limite admitido em cada caso pela Administração.

A dúvida crucial, que se antepõe ao intérprete, é, exatamente, com relação à expressão partes, todavia, este dispositivo deve ser interpretado em comunhão com $o$ inciso VI do artigo 78.

É princípio assente de hermenêutica que o dispositivo a ser interpretado deve ser comparado com outros do mesmo repositório ou de leis diferentes, porém tendo o mesmo objeto. Leciona CARLOS MAXIMILIANO, alicerçado na melhor doutrina (COELHO DA ROCHA, BORGES CARNEIRO, TRIGO DE LOUREIRO e CARLOS DE CARVALHO):

"Cada preceito, portanto, é membro de um grande todo; por isso do exame em conjunto resulta bastante luz para o caso em apreço."

O entrelaçamento de um princípio com outros é de fundamental importância, ou, como informa o Ministro LUIZ VICENTE CERNICCHIARO, "o Direito, como sistema, é uno. Não admite contradição lógica. As normas harmonizam-se" (cf. Direito \& Justiça, Correio Braziliense, Brasília, 14.4.97).

Desde $C E L S O$, em Roma, emitir parecer ou julga a lei, separadamente, ao invés de fazê-lo em conjunto, é extremamente condenável, porque contrário ao direito. Sabe-se, com SAREDO, que não se presumem dispositivos contraditórios, devendo as palavras harmonizarem-se entre si (cf. Hermenêutica e Aplicação do Direito, de CARLOS MAXIMILIANO, Livraria Freitas Bastos, 6ª edição, 1957, pp. 164 e 172).

\section{Subcontratação}

À primeira vista, a lei somente permitiria a subcontratação de algumas partes do objeto do contrato (e não a totalidade), se interpretado isoladamente o artigo 72, friamente, sem o auxílio do inciso VI do citado artigo 78. Não obstante, ambos os preceitos entrelaçam-se, intimamente, e não podem ser analisados, isoladamente.

Se a contratada, na execução do contrato, sem prejuízo das responsabilidades contratuais e legais, pode subcontratar partes, até o limite admitido em cada caso, pela Administração (artigo 72) e o inciso VI do citado artigo 78 cataloga como 
motivo para rescisão do contrato a subcontratação total ou parcial do seu objeto, não admitida no edital e no contrato, é curial que a subcontratação total é consentida. Do contrário, este inciso não estaria fazendo referência à subcontratação total, visto que a lei não contém palavras inúteis, tendo estas sempre algum significado. Há que se descobrir, portanto, o porquê de sua permanência no texto.

A conclusão insofismável é de que a lei realmente não obsta a subcontratação total de execução do contrato, nem tampouco a cessão (transferência) total ou parcial, com o que está de acordo DIÓGENES GASPARINI, ao avisar que:

"o Estatuto Federal Licitatório vai mais além e admite a subcontratação total (toda a execução do contrato passa para um terceiro sem que o subcontratante se desvincule do contrato) do objeto e a cessão (transferência total ou parcial dos direitos decorrentes do contrato a terceiro, com o cedente desvinculando-se no todo ou em parte do contrato cujos direitos foram cedidos), se essas operaçóes estiverem previstas e reguladas no edital. Observe-se que o Estatuto Federal Licitatório só considera motivo de rescisão contratual a subcontratação, total ou parcial, e a cessão e a transferência, total ou parcial, se não previstas no edital e no contrato. Consignadas no instrumento convocatório, essas operações são válidas, desvinculando-se ou não, em parte ou por completo, o contrato do contratante. Não cabe, assim, falar-se em fraude à licitação, ainda que alguém não selecionado por esse procedimento, acabe por relacionar-se contratualmente com a Administração Pública" (cf. Direito Administrativo, Saraiva, 4a edição, 1995, pp. 396/7).

ADILSON ABREU DALLARI, ao tratar de contrato de obra pública, estuda, com profundida, esta tormentosa questão, ainda que sob o regime jurídico do Decreto 73.140, de 9.11.73, que não difere basicamente do direito atual, e conclui:

"desde que haja prévia aquiescência da Administração, não há por que impedir-se a transferência de contrato realizado com esta, mesmo que com dispensa de licitação, pois, in casu, nem se propõe a questão da licitação" (cf. Cadernos FUNDAP, publicação da Fundação do Desenvolvimento Administrativo, $n^{0} 11$, de julho de 1985, pp. 27 a 38).

$\mathrm{O}$ inciso VI do artigo 78 é bastante rico em conteúdo, porque, ao contrário do artigo 72, arrola outras hipóteses, além da subcontratação, que se não confunde com aquelas. E, mais, pressupõe que no edital e no contrato a Administração já preveja esta faculdade.

Portanto, duas são as condições substantivas: admissão do quantum e previsão no edital e no contrato. Já o artigo 72 é mais singelo e ficará vazio, se não se fizer a estreita comunhão com aquele preceito.

A doutrina, em uníssono, autoriza a subcontratação da execução do objeto do contrato, conquanto alguns autores o façam com restrição, não permitindo a subcontratação total, senão apenas parcial, desde que prevista obrigatoriamente no edital $\mathrm{e}$ no contrato, com o apoio da mais Alta Corte de Contas da União e do Estado de São Paulo.

Sem dúvida, o contrato administrativo é pessoal, sem ser personalíssimo, e a lei permite que, excepcionalmente, a contratada transfira ou ceda a terceiros, a execução do objeto, dada a concentração, racionalização e especialização de atividades. 
A subcontratação ou o cometimento a terceiros de partes da execução do objeto e de suas obrigações contratuais é, pois, perfeitamente lícita, desde que haja previsão desta faculdade no edital e no contrato, até o quantitativo admitido pela contratante.

A contratada responde perante a contratante pela execução total do objeto contratado e não há qualquer relação entre a contratante e a subcontratada, de modo que, também, pelos atos ou omissões desta, ela é plenamente responsável. A responsabilidade da contratante é plena, legal e contratual.

Nada impede que haja subcontratações sucessivas ou simultâneas, como por exemplo, a subcontratação concomitante da parte hidráulica e da parte de alvenaria e da parte elétrica ou das fundações. E é o que ocorre com freqüência.

O saudoso tratadista HELY LOPES MEIRELLES, interpretando a lei vigente, consente que a contratada defira, sob sua inteira responsabilidade, a execução de alguns serviços técnicos e especializados a terceiros ou a consórcios de pessoas jurídicas ou físicas, conquanto possam ser solidariamente responsáveis, pela parte executada, na forma avançada (cf. Direito Administrativo Brasileiro, Malheiros Editores, $20^{a}$ edição, 1995, pp. 21 1/2122, e Licitação e Contrato Administrativo, cit.).

MARÇAL JUSTEN apregoa que a Administração, caso a caso, faça uma avaliação da conveniência de propiciar a subcontratação, segundo os limites prefixados (cf. Comentários à Lei de Licitações e Contratos Administrativos, AIDÊ Editora, $4^{\mathrm{a}}$ edição, 1996, p. 416). CARLOS PINTO COELHO MOTTA adverte que o tema, efetivamente, é polêmico, quanto ao quantitativo (cf. Eficácia nas Licitações e Contratos, Del Rey, 1994, pp. 230/1). CAIO TÁCITO assegura que, por ser contrato realizado, intuitu personae, a subcontratação deve estar prevista no contrato ou no termo aditivo e no caderno de encargos ou instruçāo de serviço, recebendo total aprovação de TOSHIO MUKAI (cf. O Novo Estatuto Jurídico das Licitações e Contratos Públicos, Editora Revista dos Tribunais, 1993, p. 78).

JESSÉ TORRES PEREIRA JÚNIOR, em alentado comentário ao artigo 72, deduz que é proibida a subcontratação total do contrato, mas admite a subcontratação parcial, desde que previsto no edital e no contrato (cf. Comentários à Lei das Licitações e Contratações da Administração Pública, Renovar, Rio, 1995, $3^{\mathrm{a}}$ edição, pp. $450 \mathrm{a} 453$ ). Nem outroéo pensamento de ROBERTO RIBEIRO BASILLI, ao afirmar que a contratada poderá subcontratar partes da obra, serviço ou fornecimento, mediante prévia aquiescência da Administração, e segundo os limites fixados, remanescendo sua responsabilidade legal e contratual, perante esta, inclusive no que tange à subcontratação (cf. Contratos Administrativos, Malheiros Editores, 1996, p.p. 103/104), destacando-se, ainda, autores do porte de SÉRGIO FERRAZ e LÚCIA VALLE FIGUEIREDO, que comungam da mesma opinião.

FLORIANO AZEVEDO MARQUES NETO ilustra, com muita propriedade, a hipótese de a Administração contratar uma empresa, para executar uma ponte, e afiança que não se está pretendendo que ela execute, por si própria, todos os serviços que compõem tal obra, o que seria absolutamente inviável, não importando, pois, se as fundaçōes se fizerem por subcontratada, empresa especializada, porque a contratada responderá por vícios que advierem e a relação da Administração será sempre com esta, diretamente (cf. parecer, in Boletim de Licitações e Contratos, Editora NDJ de São Paulo, número 2, de fevereiro de 1996. 
Outra regra de ouro diz respeito à precisão e clareza com que devam ser descritas as condições para a execução dos contratos, consubstanciadas nas cláusulas que definem os direitos, obrigações e responsabilidades, tudo em consonância com os termos da licitação e da proposta a que ficam vinculados. Mesmo os contratos, que tiveram a dispensa ou a inexigibilidade declaradas, ficam sujeitos aos termos do ato que os autorizou e da proposto. Nada escapa ao seu controle.

Assim, o artigo 66 traça um mandamento essencial, mandando as partes cumprir as cláusulas convencionadas e as normas desta lei. porque o contrato é lei entre as partes. respondendo cada qual pelas consequiências de seu descumprimento, total ou parcial.

O diploma legal, sob comento, no artigo 78 , VI, traz à colação, além da subcontratação. outros institutos, como a associação do contratado com outrem, a cessão ou transferência, a fusão, cisão ou incorporação, que se não confundem entre si, porque totalmente distintos.

Faz-se necessário um exame, ainda que ligeiro, dessa cláusula legal.

A fusão. a incorporação e a cisão, em face da legislação vigente, podem operar-se entre sociedades de tipos iguais ou diferentes, não discrepando do projeto de alteração da lei das sociedades anônimas, enviado à sanção do Presidente da República (cf. redação final do Projeto de Lei da Câmara nº 106, de 1996 (nº 622, de 1995, na Casa de origem).

A incorporação ocorre, conforme a Lei 6.404, de 1976, quando uma ou mais sociedades são absorvidas por outra, que lhe sucede em todos os seus direitos e obrigaçōes. É uma espécie do gênero fusão, conquanto seja tratada pelo direito pátrio, de forma singular.

Leciona RICARDO BARRETO SILVA que na transformação há a presença de uma só pessoa jurídica e naquela há a participação de pelo menos duas ou mais pessoas jurídicas, não importando o tipo de sociedade (cf. Comentários a Lei das Sociedades por Ações, co-edição Instituto dos Advogados de São Paulo - Editora Resenha Tributária, 1986, volume 5, p. 378).

A fusão caracteriza-se pela comunhão de duas ou mais sociedades, para a formação de uma nova, que lhes sucederá em todos os seus direitos e obrigações.

$\mathrm{Na}$ cisão, uma companhia transfere parcela de seu patrimônio para uma ou mais sociedades, constituídas para esse fim ou já existentes, de sorte que a sociedade cindida se extingue, se houver versão total de seu patrimônio, ou divide-se o seu capital, se a versão for parcial.

A sociedade que absorver parcela do patrimônio da companhia cindida sucede a esta nos direitos e obrigações que se referem ao ato da cisão, mas, se ocorrer a extinção, no caso da cisão, as sociedades que absorverem parcelas do patrimônio da companhia cindida, sucederão a esta, na proporção dos patrimônios líquidos transferidos, nos direitos e obrigações não relacionados.

WILSON DE SOUZA CAMPOS BATALHA alerta que, nas simples transferências de parcelas do ativo, mediante pagamento do preço. à vista ou a prazo, as sociedades existentes ou constituídas ad hoc, não se caracteriza a cisão (cf. Direito Processual Societário. Forense. 1986, p. 250). 
Já a sub-rogação resulta da lei ou da convenção (artigos 985 a 990 do Código Civil). Sub-rogar é colocar uma coisa em lugar de outra ou uma pessoa substituindo outra, numa relação jurídica e WASHINGTON DE BARROS MONTEIRO recorda que, na sub-rogação pessoal, à pessoa sub-rogada ficam garantidos os mesmos direitos e ações que cabiam àquela (cf. ainda CLOVIS BEVILAQUA, Código Civil dos Estados Unidos Comentado, Livraria Francisco Alves, 1955, volume IV/115119). Arnoldo Wald sustenta também que a sub-rogação pode ser legal e convencional, conforme o caso (cf. Parecer, publicado nos Cadernos de Direito Tributário e Finanças Públicas, da Editora dos Tribunais 17/57.)

\section{Cessão do contrato}

A cessão opera-se pela transferência ou substituição da contratada por outra. $O$ cessionário coloca-se na posição da contratada, assumindo sua postura.

A pessoa do contratado substitui-se para todos os efeitos, sub-rogando-se o cessionário em todos os seus direitos e obrigações, ou, como ensina o douto CARLOS PINTO COELHO MOTTA, citando o escritor EDUARDO GARCIA DE ENTERRIA, o direito espanhol distingue entre cessão e subcontratação, de sorte que a legislação específica o admite, tanto em matéria de obras, quanto em matéria de serviços.

Cessão deriva do latim cessio, com o significado de ceder, traspassar, e $P L A ́$ CIDO E SILVA conceitua-a, segundo a boa técnica jurídica, como:

"o contrato, a título oneroso ou gratuito, pelo qual a pessoa titular de créditos ou de direitos, transfere a outra esses mesmos créditos ou esses mesmos direitos, com abstração das coisas sobre que recaem. Quer isto significar que, em regra, a cessão não se mostra um contrato especial, isto é, não se indica uma obrigação, mas, particularmente, o cumprimento dela, em vista do que se motiva e se autoriza a convenção, que vem garantir ao credor do cedente (salvo o caso de cessão gratuita) a existência jurídica e válida de seu crédito" (cf. Vocabulário Jurídico, Forense, Rio, 1982, (/419).

E JOSÉ NAUFEL define-a como:

"o ato pelo qual uma pessoa transfere para outrem um ou mais direitos de quem é titular" (cf. Novo Dicionário Jurídico Brasileiro, José Konfino - Editor, Rio, 1959, 2a edição, I/ 316-317).

O advogado mineiro ALCY TAYLOR DA COSTA, examinando a cessão do contrato com a Administração, para o Departamento de Obras Públicas do Estado de Minas Gerias-DEOP - MG, ratifica o pensamento dominante de que esse tipo de contrato é pessoal mas nem sempre personalíssimo, dado que:

"Nos dias atuais, a complexidade e o gigantismo de algumas obras estatais, a velocidade a elas imprimida para atendimento do interesse público impõem uma relação dinâmica entre as partes permitindo essa participação" (cf. parecer inédito aprovado pelo seu diretor-geral, engenheiro RODRIGO OCTAVIO COUTINHO FILHO, em 8 de março de 1996, e recebeu o placet do tratadista CARLOS PINTO COELHO MOTTA). 
A advogada MARIA ELIZABETH MARTINS COSTA DO AMARAL, neste mesmo parecer, arrimada nas preleções de SÍLVIO RODRIGUES E SILVA PACHECO, conclui com inteira segurança, que:

"a cessão de contrato é instituto de direito com existência jurídica amplamente aceita; que existe previsão legal para a mesma, conforme demonstram os citados art. 78, inciso VI, da Lei 8.666/93 e art. 27 da Lei 8.987/95; posição doutrinária favorável, e consuetudinária prática por parte das Administrações na aplicação deste instituto do Direito Privado nos Contratos Públicos; concluo ser perfeitamente cabivel a sua utilização, na certeza de que nenhum impedimento ou objeção quanto a sua legalidade poderá ser questionada por parte de terceiros se efetivada na forma prescrita legal e doutrinária" (cf. Parecer DEOP - MG cit.).

Com paciência de verdadeira ourivesaria, JAYME RIGUEIRA, chefe da Procuradoria daquele órgão, infere que:

“a cessão, via de regra, se processa após algum tempo e por conseqüência do surgimento de fatos supervenientes e que deixam claro, de certa forma, a impossibilidade material do prosseguimento da obra com o contratante original. No longo caminho que temos perlustrado, na pesquisa diuturna do direito e suas nuances, não nos deparamos com um só dispositivo legal que impusesse normas impeditivas ao instituto da cessão do contato administrativo, nos limites consagrados na lei." (cf. parecer cit.).

FLORIANO P. AZEVEDO NETO discorre, com extremada sensibilidade, acerca da possibilidade jurídica de sub-rogação, nos direitos advindos de parcela de contrato de execução de obra pública, sem que se caracterize burla ao artigo $37 \mathrm{da}$ Constituição Federal. E o estudo da cessão do contrato também não fica sem uma ampla apreciação.

Como exceção trata da sub-rogação, da transferência e da cessão de contrato administrativo, traçando ampla distinção entre esses institutos. Com PLANIOL E SILVO RODRIGUES, infere referir-se a primeira mais especificamente "à cessão de crédito a partir do pagamento de dívida por terceiro" (cf. Consulta, in Cadernos de Direito Tributário e Finanças Públicas, da Revista dos Tribunais, 13/191-213).

Este autor, citando vasta doutrina e alicerçado na monografia de DIMAS DE OLIVEIRA CÉSAR, aceita o conceito de substituição de um sujeito por outro, como titular da relação contratual e não descarta poder a contratada proceder a cessão do contrato, desde que, como expressa anuência da Administração contratante, isto por que, para que o impedimento ocorra, mister se faz que cláusula proibitiva esteja inserida no contrato.

Mas acrescenta FLORIANO AZEVEDO, mesmo que possível a cessão, por não estar configurada a obrigação personalíssima, a Administração só há de concordar se tiver certeza de que a cessionária está forrada das condições técnicas, financeiras, jurídicas e econômicas (cf. consulta cit.).

A autorização dependerá sempre das circunstâncias e de cada caso, em particular.

MARÇAL JUSTEN apresenta um exemplo, realmente, digno de consideração, ao afirmar que, numa locação, a cessão do contrato, não produzirá qualquer prejuízo 
para a contratante (cf. op. cit., p. 433). Pode-se acrescentar, sem qualquer temor, que a cessão, se feita com anuência e prevista no edital e no contrato, efetivamente nenhum prejuízo trará.

Destarte, juridicamente, não há impedimento, conforme deflui da cristalina seta indicativa do inciso VI do artigo 78 do vigente diploma legal, que erige como transgressão administrativa a cessão ou transferência total ou parcial, não admitidas no edital e no contato. A contrario sensu, nenhum óbice existe, guardado o quantitativo previsto no edital e no contrato.

Assim, a obrigação intuitu personae, que caracteriza quase todos contratos administrativos, não se confunde com a obrigação personalíssima, própria de apenas alguns contratos, como por exemplo, um contrato referente a uma obra de arte, uma narração evocativa de um feito, contratada com um escritor de talento indiscutível e especializado em determinado assunto e a realização de uma pintura, por um pintor renomado. Nestes casos, obviamente, proibida estará a cessão, vez que o talento e o próprio eu do artista deverão estar presentes. E não se transmitem.

\section{Direito comparado}

No Direito Comparado, os autores, em uníssono, conferem ao contrato com a Administração características singulares, agasalhadas com prerrogativas, advindas das cláusulas extravagantes e fixam o caráter pessoal, na execução do contrato. Entretanto, nem por isso deixam de traçar algumas exceções, que cabem perfeitamente.

MARIENHOFF, com o apoio de BIELSA, JÈZE, VÉASE E LAUBADÈRE, defende as limitaçōes que lhe são impostas, não obstante, permite a cessão e a subcontratação, se a Administração consentir expressamente (cf.. Tratado de Derecho Administrativo, $3^{\mathrm{a}}$ edicion atualizada, Abeledo - Perot, Buenos Aires, III - A/316317).

JOSÉ ROBERTO DROMI registra que, em princípio, esses contratos devem ser executados pessoalmente pela contratada, mas consente na cessão e na subcontratação ou contração derivada, se a Administração autorizar, expressamente (cf.. La Licitación Pública, Editorial Astrea, Buenos Aires, 1985, p.p. 54/55), em harmonia com o pensamento de MANUEL MARIA DIEZ (cf. Manual de Derecho Administrativo, com a colaboração de TOMÁS HUTCHINSON, Editorial Plus Ultra, $4^{\mathrm{a}}$ edição, Buenos Aires, $\mathrm{I} / 353$ ) e de BERÇAITZ. Este renomado autor mostra que esses contratos, em regra, não podem ser transferidos, contudo não se opõe à subcontratação parcial, se houver autorização da Administração, a qual até pode ser útil a esta e indispensável à contratante, o que se faz correntemente (cf. Teoría General de los Contratos Administrativos, Depalma, 1980, pp. 354/355).

\section{Jurisprudência}

As Cortes Superiores de Contas têm-se pronunciado, com muita ênfase, acerca destes temas, de significativa importância, não se omitindo na sua prerrogativa constitucional de zelar pela coisa pública. 
O TRIBUNAL DE CONTAS DA UNIÃO tem pautado sua jurisprudência, no sentido de que a subcontratação parcial é lícita. se prevista no edital e no contrato.

O Relator. Ministro PAULO AFFONSO MARTINS DE OLIVEIRA, com a aquiescência do Pleno. determinou que o contrato fosse firmado nos exatos termos do artigo 72 da Lei 8.666/93, vale dizer, concordou com a subcontratação, desde que observados a norma legal e os termos contratuais, ainda que realizada após a licitação (cf. Decisão 128/94, Ata 8/94. Processo TC 012262/93-5, in DOU de 28.3.94, p. 4.515).

Na decisão 305/96, o Pleno convenceu-se da tese esposada pelo Ministro PAULO AFFONSO MARTINS DE OLIVEIRA, não admitindo a subcontratação, porque não prevista no edital e no respectivo contrato. Neste havia proibição peremptória de subcontratação (cf. Ata 14/96, Processo TC 018257/95, data da Sessão: 29.5.96, in DOU de 17.6.96). Ex contrario, permite-se.

O Ministro-Relator. LINCOLN MAGALHÃES DA ROCHA, citando as lições de HELY LOPES MEIRELLES, teve seu voto aprovado pelo Plenário, ao assentar que a subcontratação somente é possível, se for prevista no edital e no contrato, e desde que trate de partes da obra e referentes a certos serviços técnicos realizados por empresas especializadas, sob a responsabilidade integral do contratado (cf. Decisão sigilosa 207/96, Ata 15/96, Processo TC 014318-95-4 e TC 750014-96-2 (Representação), in DOU de 29.4.96, p. 7.321).

Ainda o MINISTRO LINCOLN MAGALHÃES DA ROCHA, em decisão adotada pelo Plenário, insurgiu-se contra a subcontratação, porque realizada sem a anuência da contratada (cf. ACÓRDÃO sigiloso 165/95, Ata 54/95, Processo 013245/93-7, in DOU de 15.12.95, p. 21.196), o que corrobora a tese de que lícita é a subcontratação, se resguardada pela previsão no edital e no contrato, como quer a lei.

O TRIBUNAL DE CONTAS DO ESTADO DE SÃO PAULO, pela Primeira Câmara, considerou legal o contrato, visto que a subcontratação fora prevista, em cláusula contratual e autorizada pela FEPASA e pelo BANCO MUNDIAL, por meio de aditamento. Conquanto regido pelo Decreto - lei 2.300/86, dada a similitude com a atual lei, este acórdão tem plena atualidade (cf. ata da $34^{\mathrm{a}}$ sessão ordinária de 27.9.93. DOE de 5.10.93, pp. 38-41, Relator Substituto de Conselheiro LUIZ OLAVO DE MACEDO COSTA e Conselheiro CLÁUDIO FERRAZ DE ALVARENGA), assim também o aditivo e a despesa foram julgados legais (cf. DOE de 8.11.94, p. 55 e 4.11 .95 , p. 56).

Esse mesmo Tribunal, pelo Pleno da Segunda Câmara, em acórdão relatado, pelo Substituto de Conselheiro, CARLOS BORGES DE CASTRO e com a presença dos Conselheiros, RENATO MARTINS COSTA e EDGARD CAMARGO RODRIGUES, julgou ilegal a subcontratação de serviços, porque esta ocorreu antes da adjudicação do objeto à vencedora do certame e porque não houve prévia autorização da Prefeitura - contratante, contrariando o item 16.2 do edital, bem como a cláusula 8, parágrafo único do contrato e ainda em face das publicações extemporâneas, pois "a recorrente não apresentou a data real da assinatura do ajuste da subempreitada ou outra prova conclusiva, prejudicando, assim, a credibilidade das afirmações feitas a respeito". Não se opôs, portanto, à subcontratação, desde que se conforme com a lei e, ipso facto, com o contrato e com o edital. 
O Conselheiro RENATO MARTINS COSTA deixou claro em seu lúcido VOTO que a ilegalidade do certame ficou evidenciada porque essa subcontratação se dera 36 dias antes da adjudicação à empresa vendedora (cf. TC1464/006/92, DOE de 23.5.96, pp. 21/22, republicado em 24 seguinte, pp. 43/44). Também aqui ficou evidenciado que a oposição se deu tão-somente porque não se conformou com as exigências da lei.

O Relator, Substituto de Conselheiro, CARLOS ALBERTO DE CAMPOS, em seu precioso pronunciamento, relatando o processo TC 5239/029/91, na Primeira Câmara, teve o aval unânime de seus pares, julgando legais a concorrência, o termo de sub-rogação, transferindo o contrato firmado mediante o sub-rogação, e as despesas deles decorrentes. Trata-se de contrato de construção entre a Secretaria da Saúde e a Mendes Júnior, transferido à Construtora Estoril (decisão publicada no DOE de 23.6.93, p.p. 59-60, acórdão publicado no DOE de 14.7.93, p. 35).

O Pretório Paulista julgou legais o termo de cessão contratual com sub-rogação em direitos e obrigações "transferindo todos os direitos e obrigações decorrentes do contrato e seus eventuais aditivos" e as despesas dele decorrentes. Trata-se, in casu, de contrato de construção de prédio de delegacia (decisão publicada no DOE de 24.5.95, p. p. 21 a 23, e acórdão publicado no DOE de 15.6.95, p. 34, ata da sessão extraordinária da Primeira Câmara, realizada em 16.5 .95 - TC 56480/033/88, Relator: CLÁUDIO FERRAZ DE ALVARENGA, acompanhado dos CONSELHEIROS EDGARD CAMARGO RODRIGUES e CARLOS ALBERTO DE CAMPOS).

Na sessão ordinária do TRIBUNAL PLENO, realizada em 22.3.95, o Plenário, por votação unânime, presentes os Conselheiros CLÁUDIO FERRAZ DE ALVARENGA, RELATOR, ANTONIO ROQUE CITADINI, EDGARD BITTENCOURT CARVALHO, EDGARD CAMARGO RODRIGUES, FULVIO JULIÃO BIAZZI e RENATO MARTINS COSTA, conheceu do recurso ordinário e, considerando as razões apresentadas pela origem, esclarecendo que o anexo $V$ do edital (minuta do contrato) na sua cláusula VI, permitia expressamente a cessão do contrato, desde que com o consentimento da contratante, exigência que foi cumprida, deu-lhe provimento para o fim de, reformando o v. acórdão recorrido, julgar legais a tomada de preços, o contrato, o termo de cessão e transferência, os termos de aditamento de folhas 179 e 195 e as despesas decorrentes (cf. decisão publicada no DOE de 23.5.95, p.p. 17-20, republicada no DOE do dia seguinte, p.p. 13-15; acórdão publicado no DOE de 11.10.94, p. 33, TC 23495/026/92).

No Processo TC 67764/033/88 - DOP 6689387, a Corte de São Paulo, ensinou ser nulo o contrato verbal com a Administração, alicerçando no artigo $51, \S 1^{e}$, do Decreto - lei 2.300/86 (idêntico ao atual diploma legal - cf. artigo 86 do mencionado decreto - lei c/c o artigo 31 da lei paulista 6.544/89). Entrementes, no contrato de construção de prédio da delegacia de Monte Alto, a Primeira Câmara, na sessão ordinária realizada em 12.9.95, pelos votos dos Conselheiros, CLÁUDIO ALVARENGA, relator, FÚLVIO JULIÃO BIAZZI, presidente, e EDGARD CAMARGO RODRIGUES, decidiu julgar legais o termo de cessão contratual com sub-rogação em direitos e obrigações, os termos de aditamento, o termo de recebimento definitivo etc. (ACÓRDÃO publicado no DOE de 27.9.95, p. 19). 
Este Tribunal Maior de Contas do Estado, sem dúvida, contemplou a subcontratação, a sub-rogação e a cessão do contrato, com sustentação na lei federal (nacional, no que diz respeito aos princípios gerais) e na lei paulista.

O TRIBUNAL DE CONTAS DO ESTADO DE MINAS GERAIS, por unanimidade, chancelou a validade da sub-rogação de contrato, desde que prevista no ordenamento convocatório (cf. Consulta $\mathrm{n}^{\mathrm{o}}$ 108746-1/93. Sessão de 26.8.93, Relator LUIZ BACCARINI, in Revista do Tribunal de Contas do Estado de Minas Gerais, ano XI, $\mathrm{n}^{\mathrm{0}} 3, \mathrm{p} .223$ ).

\section{Conclusão}

O contrato com a Administração Pública centra-se primacialmente na Lei $n^{0}$ 8.666, de 1993 e suas alterações posteriores, aplicando-se-lhe, supletivamente, as disposições de direito privado (Código Civil, Código Comercial, Lei das Sociedades por Ações, Lei de Locação de Imóveis Urbanos etc.), e a teoria geral dos contratos e rege-se, basicamente, pelas suas cláusulas e pelas normas de direito público. $O$ contrato, essencialmente formal, vincula-se obrigatoriamente ao edital ou ao instrumento convocatório e deverá espelhar com precisão as condições, direitos e obrigações das partes contratantes. É escrito e submete-se às rígidas regras desta lei, permitindo-se excepcionalmente o contrato verbal, se de pequenas compras, de pronto pagamento, feitas em regime de adiantamento, e que não ultrapasse o limite previsto no artigo 23 , II, a, desse diploma.

O contrato com a Administração Pública é, em regra, pessoal, não obstante, a lei comentada permite, que, na execução do contrato, a contratada subcontrate ou ceda (transfira) partes da obra, serviços ou fornecimento, até o limite admitido, em cada caso.

A lei paulista é mais generosa e faculta, sem prejuízo das responsabilidades legais e contratuais, a subcontrataçāo de parte da obra, serviço ou fornecimento, na forma do pactuado na cláusula própria, ou independentemente dessa previsão, nos limites fixados, caso a caso, pela Administração (artigo 69 da Lei de 22 de novembro de 1989).

A contratada, apesar da subcontratação consentida, legal e contratualmente, até os limites previstos, continua com total responsabilidade legal e contratual.

A cessão e a sub-rogação não foram rejeitadas, porque encontram sustentação no direito positivo.

Interpretando a lei vigente, a doutrina não se tem furtado de marcar sua posição, com relação a este tema, que não é novo. A lei anterior, o Decreto - lei $n^{2} 2.300$, de 1986, continha normas idênticas.

Também a lei que rege as concessões e permissões, de obras e serviços públicos - Lei 8.987, de 13 de fevereiro de 1995, consagra o mesmo princípio.

Alguns autores admitem, a subcontratação total, sem qualquer restrição, conquanto exijam esteja, expressamente, prevista esta faculdade no edital e no contrato. A aquiiescência da contratada é, pois, condição sine qua non. 
Entretanto, predomina o entendimento doutrinário, de que a subcontratação pode fazer-se, mas apenas de partes do objeto (não a totalidade, somente até o quantitativo descrito no edital e no contrato), desde que admitida, no edital e no contrato.

As outras modalidades também são autorizadas, mas sempre com vistas ao edital e ao contrato.

A regra vigente - artigo 72 - permite a subcontratação até o limite admitido, em cada caso, isto é, deverão o edital e o contrato descrever o limite autorizado para a subcontratação, sem prejuízo da responsabilidade da contratada, que remanesce incólume.

O inciso VI do artigo 78 distingue as hipóteses de transgressão, e impõe a exigência da previsão no edital e no contrato, corroborando o artigo 72, e não rejeita, antes coonesta a cessão e as outras modalidades ali previstas, desde que inseridas no edital e no contrato, segundo o quantitativo neles previsto.

O Tribunal Maior de Contas da União admite a subcontratação de parte, não de todo o objeto, desde que haja previsão no edital e no contrato, até o limite nele estipulado.

A seu turno, a cessão e a sub-rogação do contrato não é defesa, segundo as preleções de abalizados doutrinadores, se prevista no edital e no contrato, contando com a autorização da contratante.

Esta é também a orientação dos Tribunais Paulista e Mineiro, que admitem expressamente a cessão e a sub-rogação.

\section{Concluindo:}

1. Subcontratação, na linguagem da Lei de Licitações e Contratos - Lei 8.666, de 21 de junho de 1993, e suas alterações posteriores, é o cometimento a terceiros de partes da execução do objeto do contrato.

2. A subcontratação não se confunde com a associação da contratada com outrem, nem com a cessão, transferência, fusão, cisão ou incorporação.

3. A subcontratação está submetida à regência da Lei 8.666, de 21 de junho de 1993, e alterações posteriores, bem como às disposições do direito privado, subsidiariamente.

4. A subcontratação de um contrato de obra, serviço ou fornecimento perfeitamente lícito.

5. A subcontratação é permitida, desde que esteja prevista expressamente no edital e no contrato, até o limite ali consignado e a responsabilidade originária da contratada permanece inalterada.

6. A cessão do contrato administrativo é lícita e conforma-se com a melhor doutrina e com o direito vigente. A interpretação do inciso VI do artigo 78 da Lei 8.666/93 conduz, insofismavelmente, a essa conclusão.

7. A cessão poder ocorrer, desde que prevista no edital e no contrato, de conformidade com o quantitativo ali consignado, cessando a responsabilidade da contratada.

8. A sub-rogação pode ocorrer, nas mesmas condições da cessão. 
9. A jurisprudência do Tribunal de Contas da União tem-se pautado, no sentido de proibir a subcontratação total e, ipso facto, aquiescer na subcontratação de partes (não a globalidade) do objeto do contrato, exigindo a sua previsão no edital e no contrato, até o limite consignado.

10. Alguns tribunais estaduais têm manifestado, iterativa e torrencialmente, sua plena aquiescência à subcontratação, à sub-rogação e à cessão do contrato.

11. O contrato entre a contratada e a subcontratada faz-se diretamente entre estas, conquanto fiquem mantidos os vínculos entre a contratante e a contratada e total responsabilidade desta. 